\title{
Trends in coastal upwelling intensity during the late 20th century
}

\author{
N. Narayan, A. Paul, S. Mulitza, and M. Schulz \\ MARUM - Center for Marine Environmental Sciences and Faculty of Geosciences, University of Bremen, Germany \\ Received: 21 January 2010 - Published in Ocean Sci. Discuss.: 19 February 2010 \\ Revised: 25 August 2010 - Accepted: 27 August 2010 - Published: 22 September 2010
}

\begin{abstract}
This study presents linear trends of coastal upwelling intensity in the later part of the 20th century (19602001) employing various indices of upwelling, derived from meridional wind stress and sea surface temperature. The analysis was conducted in the four major coastal upwelling regions in the world, which are off North-West Africa, Lüderitz, California and Peru. The trends in meridional wind stress showed a steady increase of intensity from 1960-2001, which was also reflected in the SST index calculated for the same time period. The steady cooling observed in the instrumental records of SST off California substantiated this observation further. It was also noted that the trends in meridional wind stress obtained from different datasets differ substantially from each other. Correlation analysis showed that basin-scale oscillations like the Atlantic Multidecadal Oscillation (AMO) and the Pacific Decadal Oscillation (PDO) could not be directly linked to the observed increase of upwelling intensity off NW Africa and California respectively. The relationship of the North Atlantic Oscillation (NAO) with coastal upwelling off NW Africa turned out to be ambiguous due to a negative correlation between the NAO index and the meridional wind stress and a lack of correlation with the SST index. Our results give additional support to the hypothesis that the coastal upwelling intensity increases globally because of raising greenhouse gas concentrations in the atmosphere and an associated increase of the land-sea pressure gradient and meridional wind stress.
\end{abstract}

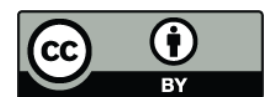

Correspondence to: N. Narayan (nnarayan@marum.de)

\section{Introduction}

Coastal upwelling systems are characterized by seasonally low sea-surface temperature (SST). Coastal upwelling results from the response of the coastal ocean to alongshore winds, leading to the production of a relatively intense current with a small offshore and a large alongshore component (e.g. Pedlosky, 1978). This causes the pumping of cooler and nutrient-rich water from the subsurface (from 50-150 m approximately) to the ocean surface.

Due to the enhanced primary production, these regions are economically important, accounting for nearly $20 \%$ of the global fish catch, even though the area constituted by the upwelling regions are less than $1 \%$ of the global ocean (Pauly and Christensen, 1994). They also play an important role in the air sea exchange of $\mathrm{CO}_{2}$. Moreover, coastal upwelling has also a profound effect on local climate.

Based on pre-1985 data, Bakun (1990) observes an increase in coastal upwelling at a global scale. He hypothesizes that this increase is due to global warming. The underlying mechanisms involve an intensification of the land-sea pressure gradient due to differential heating, which in turn causes a strengthening of upwelling-favorable winds.

In support of the "Bakun hypotheis", a significant cooling of surface waters in the coastal upwelling area off Cape Ghir (North West Africa near $30.5^{\circ} \mathrm{N}$ ) during the later part of the 20th century has been reconstruced by McGregor et al. (2007). However, Lemos and Pires (2004) find a decrease in coastal upwelling intensity off the coast of Portugal in the later part of the 20th century. Furthermore, Dunbar (1983) suggests a decrease of upwelling between 1850 and the present. While taking into account a longer timescale of 3000 years, Julliet-Leclerc and Schrader (1987) also argue that the coastal upwelling in the Gulf of California is weaker today than 1500 to 2000 years before present. These contrasting results prompted us to study the change of coastal upwelling intensity during the 20th century in further detail.

Published by Copernicus Publications on behalf of the European Geosciences Union. 
In this study we test the Bakun hypothesis at a global scale by exploiting available datasets covering a longer time period and extending to the present day. To this end, we compared the linear trends of coastal upwelling intensity, which we derived from meridional wind stress and SST, in the four major upwelling regions of the world. We also tested if basin-scale climate oscillations exert a primary control on the intensity of coastal upwelling. The analysis revealed contrasting trends, which suggested large discrepancies between the wind-stress datasets. The datasets that we regard as more reliable support an increase of coastal upwelling intensity over the later part of 20th century, which is consistent with the observation by Bakun (1990).

\section{Data and methods}

Our analysis focuses on the coastal-upwelling areas off North West Africa (near $30.5^{\circ} \mathrm{N}$ ), California (near $39^{\circ} \mathrm{N}$ ), Lüderitz (near $27.5^{\circ} \mathrm{S}$ ) and Peru (near $12.5^{\circ} \mathrm{S}$ ). Due to the lack of long-term and regional-scale measurements of vertical velocities, we used wind speed and SST as an indirect measure for assessing upwelling strength. We employed the meridional wind speed data of the Comprehensive Ocean Atmosphere Dataset (COADS; Slutz et al., 1985), the National Center for Environmental Prediction NCEP/NCAR reanalysis (Kalnay et al., 1996) and the ERA-40 reanalysis (Uppala et al., 2005) from the European Centre for Medium Range Weather Forecast. The COADS dataset has a spatial resolution of $1^{\circ} \times 1^{\circ}$, while the NCEP/NCAR reanalysis and the ERA-40 reanalysis both have a spatial resolution of $2.5^{\circ} \times 2.5^{\circ}$. For obtaining the timeseries, a small region $\left(3^{\circ}\right.$ in the cross-shore direction and $5^{\circ}$ in the alongshore direction) was defined in each of the coastal upwelling areas and the meridional wind stress was area-averaged. The data over land areas were masked out. All data were obtained at monthly resolution and averaged over time to produce annual data. The time period covered by the wind data is from 1960 to 2001. An increase in equatorward meridional wind stress was taken to indicate an increase in coastal upwelling. Wind stress was calculated from wind speed using a constant drag coefficient of 1.2. The COADS wind stress at a monthly resolution was used for calculating Pearson's correlation coefficient and the cross-correlation coefficients with climatic indices indicative of the Atlantic Multidecadal Oscillation (AMO), the North Atlantic Oscillation (NAO), and the Pacific Decadal Oscillation (PDO).

We also used the SST data from the Hadley Centre (HadISST; Rayner et al., 2003), which is a monthly dataset with a spatial resolution of $1^{\circ} \times 1^{\circ}$ that covers the time period 1870-2006. The monthly data was averaged over time to produce annual data and was used to calculate an index of coastal upwelling, which is defined as the difference of SST from an offshore location to a near shore location at the same latitude (Nykjaer and Van Camp, 1994). For this purpose, a series of locations was determined on the coast separated

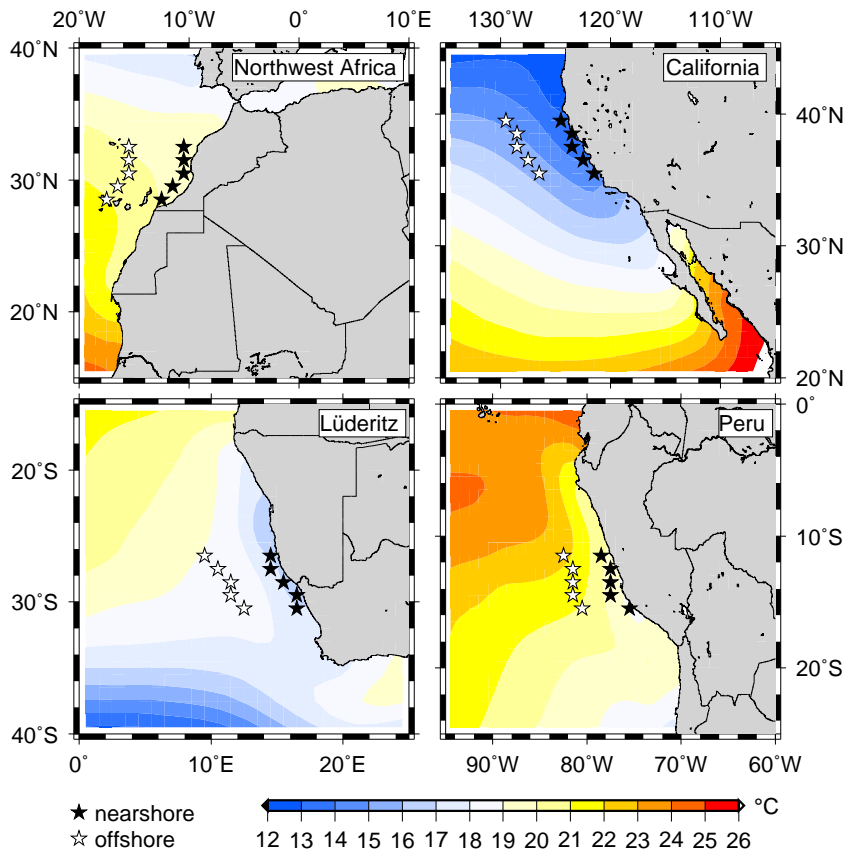

Fig. 1. Coastal (black) and offshore (white) data points for the calculation of the SST index from the HadISST dataset for the four major upwelling regions off NW Africa, California, Lüderitz and Peru. The SST index is the difference between the offshore mean SST and the coastal mean SST. The background is the long-term SST calculated from the HadISST dataset (Rayner et al., 2003).

by $1^{\circ}$ in the meridional direction. A location $5^{\circ}$ offshore from the coastal point was taken at the same latitude as the offshore data point (Fig. 1). The SST index was calculated by subtracting the SST at the coastal point from the SST at the offshore location. Through this method five different time series were obtained for each upwelling region. The average of these time series was then taken as the upwelling index. An increase of this index is taken to indicate an increase of the upwelling intensity. An SST index with monthly temporal resolution was also calculated by the above method for the correlation and cross-correlation analysis with various climatic indices.

In addition, the instrumental SST dataset provided by the California Cooperative Fisheries Investigation (CALCOFI; Bograd et al., 2003) was used in the California upwelling region to also calculate an upwelling index. The SST data east of CALCOFI station number 52 were taken as coastal data and the SST data between west of CALCOFI station number 80 were considered offshore data (Fig. 2). The data points in the Sea of Cortez were excluded. An upwelling index time series was produced by subtracting the coastal SST from the offshore SST. A time series of temperature of the top $100 \mathrm{~m}$ of the water column in the coastal area (east of CALCOFI station number 52) was also taken. Though the CALCOFI data extends from 1949-2006, there are gaps in the time series when the CALCOFI cruises were not frequent, 


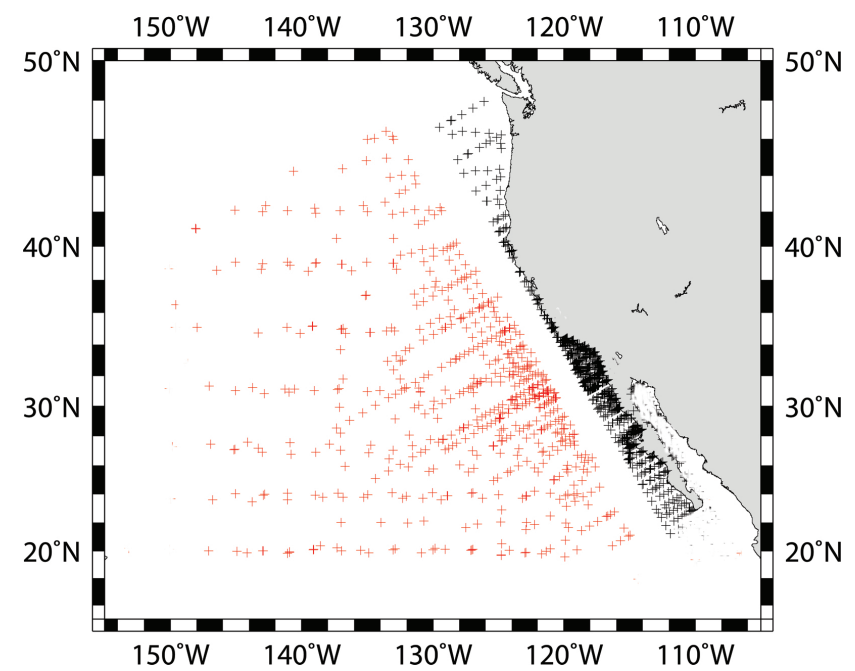

Fig. 2. CALCOFI (Bograd et al., 2003) data used to calculate the SST index. It is calculated by subtracting the area-averaged SST over coastal locations (black) from the area-averaged SST of the offshore locations (red).

especially between 1970 and 1980 . However, overall trends in the data could be used as shown in the study by Roemmich (1992). The resulting time series had a temporal resolution of three months (starting in January) and was area-averaged.

The following climatic indices at monthly resolution were used in the study:

1. The Atlantic Multi-decadal Oscillation Index (AMOI; Enfield et al., 2001), calculated from the SST data of Kaplan et al. (1998) as the de-trended area-weighted average over the North Atlantic $\left(0^{\circ}-70^{\circ} \mathrm{N}\right)$.

2. The North Atlantic Oscillation Index (NAOI; Barnston and Livezey, 1987), which is the normalised pressure difference between the Azores and Iceland averaged over the months of December, January and February.

3. The Pacific Decadal Oscillation Index (PDOI; Mantua et al., 1997), derived as the leading principal component of monthly SST anomalies in the North Pacific Ocean, poleward of $20^{\circ} \mathrm{N}$ with monthly means removed.

4. The Multivariate El Niño Southern Oscillation Index (MEI; Wolter and Timlin, 1993), based on the sea-level pressure, zonal and meridional components of the surface wind, sea surface temperature, surface air temperature and the total cloudiness fraction of the sky.

The time series of meridional wind stress and SST index were low-pass filtered using a Butterworth filter with a cutoff period of 8 years and order 12. This was done to reduce the effect of interannual variability on the long term trend. Due to the presence of gaps in the CALCOFI dataset, the low pass filtering could not be performed on it and the raw data
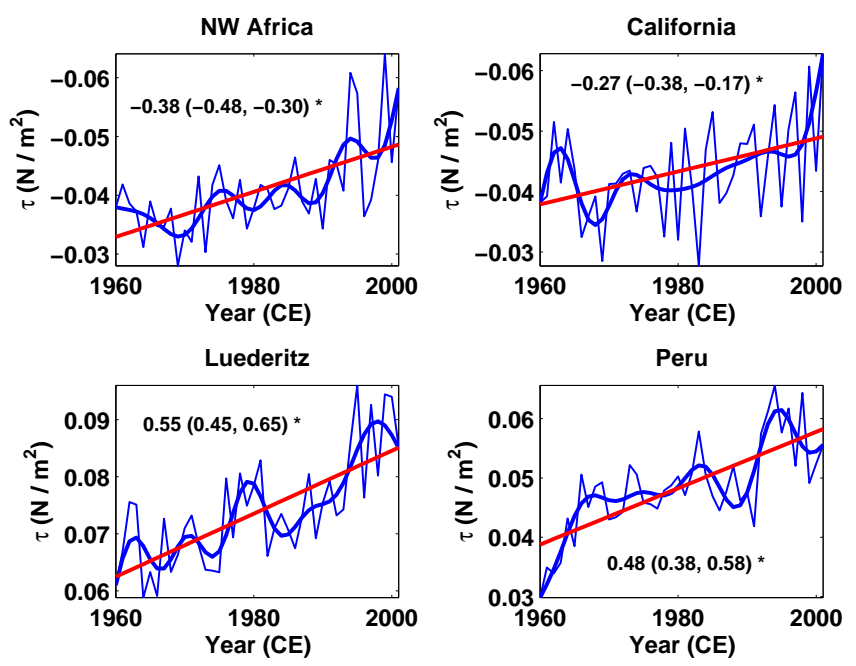

Fig. 3. Linear trends (red line) of meridional wind stress from COADS (Slutz et al., 1985) calculated by the method of least squares. All regions show a significant increase of upwelling. In the Northern Hemisphere a negative slope indicates increase of upwelling. The value of the slope and its $95 \%$ confidence interval are given in each panel (in units of $10^{-3} \mathrm{Nm}^{-2} \mathrm{yr}^{-1}$ ). A * indicates that the slope is statistically significant at the 0.05 level. Also shown are the unsmoothed time series (thin lines).

was used for the analysis. Linear trends in time series were estimated using the method of least squares. The statistical significance of the trends was estimated using a Student's ttest with the null hypothesis of a zero slope of the trend line at a significance level of 0.05 . In order to account for the autocorrelation in the time series, an effective sample size was used (Dawdy and Matalas, 1964). The correlation between time series along with the bootstrap confidence interval was estimated taking into account the serial dependence in the timeseries (Mudelsee, 2003). The cross-correlation function was calculated using the algorithm described by Orfanidis (1996). Linear trends were removed from the datasets before estimating the cross-correlation function.

\section{Results}

The COADS wind stress reveals significant increasing trends in all coastal upwelling regions (Fig. 3, Table 1). In contrast, the NCEP/NCAR wind stress (Fig. 4, Table 1) indicated a significant decrease in upwelling off NW Africa, whereas an increasing trend was observed for Lüderitz. The trends for California and Peruvian upwelling regions were statistically insignificant.

The ERA-40 (Fig. 5, Table 1) dataset showed an increasing trend in the NW African and Peru upwelling regions and a decreasing trend in the California upwelling region. In the Lüderitz upwelling region the trend observed is insignificant. 
Table 1. Summary of the inferred changes in 20th century upwelling intensity. A + sign represents an increasing trend, a - sign a decreasing trend and 0 a statistically insignificant trend. Deviation from analysis done on unsmoothed time series is shown by values in paranthesis.

\begin{tabular}{ccccccc}
\hline Region & COADS & NCEP/ & ERA-40 & CALCOFI & \multicolumn{2}{c}{ HadISST } \\
& & NCAR & & & 1870-2006 & $1960-2006$ \\
\hline NW Africa & + & - & + & NA & $-(0)$ & + \\
California & + & 0 & $-(0)$ & + & 0 & + \\
Lüderitz & + & + & $0(+)$ & NA & - & + \\
Peru & + & $0(-)$ & + & NA & - & - \\
\hline
\end{tabular}
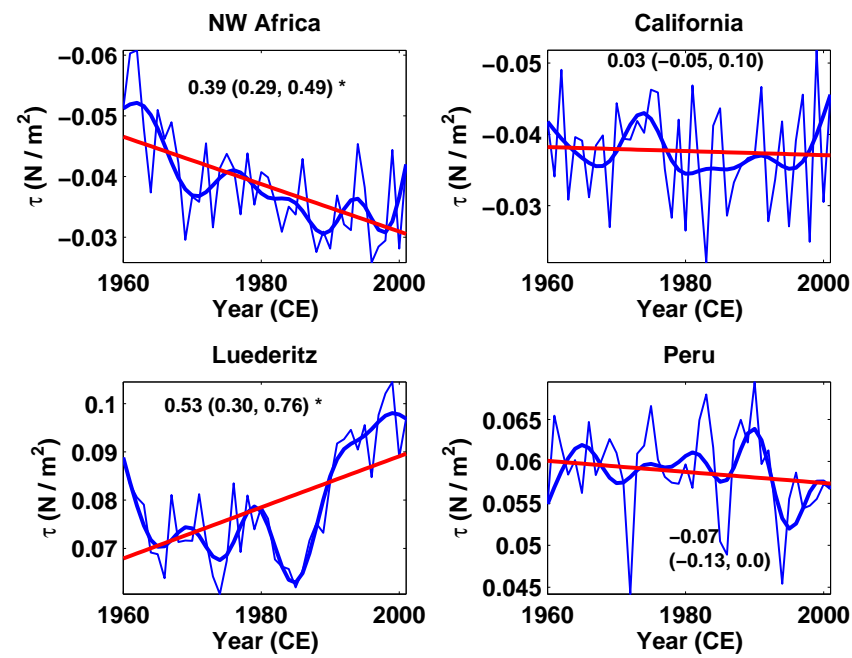

Fig. 4. Linear trends (red line) of meridional wind stress from the NCEP/NCAR reanalysis dataset (Kalnay et al., 1996) calculated by the method of least squares. NW Africa and Peru show a decrease of upwelling. There is an increase of upwelling in Lüderitz and an insignificant trend in California. In the Northern Hemisphere a negative slope indicates increase of upwelling. The value of the slope and its $95 \%$ confidence interval are given in each panel (in units of $10^{-3} \mathrm{Nm}^{-2} \mathrm{yr}^{-1}$ ). A $\mathrm{A}^{*}$ indicates that the slope is statistically significant at the 0.05 level. Also shown are the unsmoothed time series (thin lines).

As an additional proxy for upwelling intensity, the SST index was calculated for the period between 1870 and 2006 and analysed for trends (Fig. 6, Table 1). It revealed significantly decreasing trends off NW Africa, Lüderitz and Peru. In contrast, trends in the more recent part of the time series (from 1960 onwards) suggested an increase in upwelling in all regions except off Peru (Fig. 7, Table 1).

For the California system, this result is also supported by the SST index derived from the CALCOFI dataset (Fig. 8a). The coastal SST indicated a significant cooling trend throughout the sampling period (Fig. 8b). The time series produced by averaging the temperature of the top $100 \mathrm{~m}$ of the water column in the California coastal region also showed a significant cooling (Fig. 8c). Both findings confirmed the results obtained by analysing the wind and SST data from the global datasets.
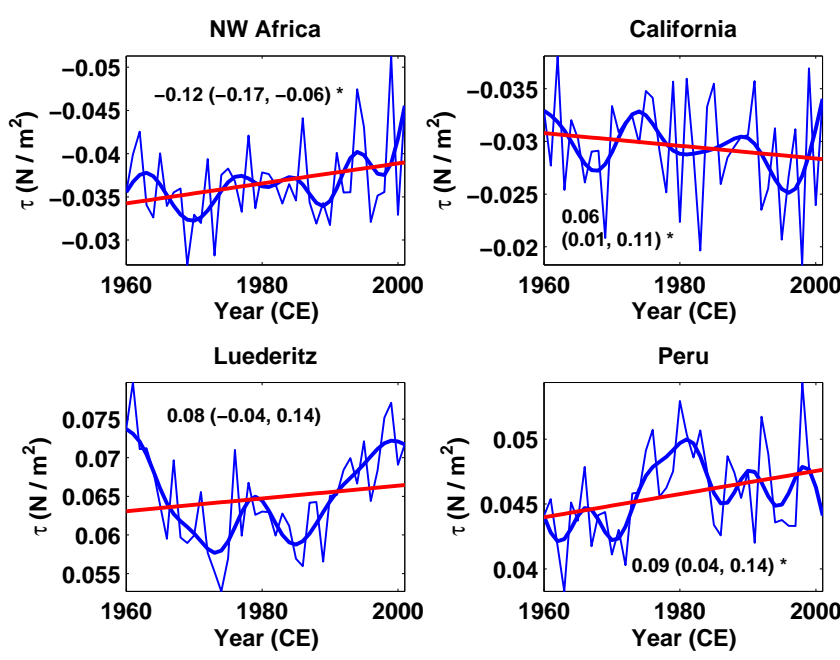

Fig. 5. Linear trends (red line) of meridional wind stress from the ERA-40 dataset (Uppala et al., 2005) estimated by the method of least squares. NW Africa and Peru show an increase of upwelling. There is a decrease of upwelling in California and insignificant trend in Lüderitz. In the Northern Hemisphere a negative slope indicates increase of upwelling. The value of the slope and its $95 \%$ confidence interval are given in each panel (in units of $\left.10^{-3} \mathrm{Nm}^{-2} \mathrm{yr}^{-1}\right) . \mathrm{A}^{*}$ indicates that the slope is statistically significant at the 0.05 level. Also shown are the unsmoothed time series (thin lines).

\section{Discussion}

On one hand, the results from analysing trends in the COADS wind stress are consistent with the hypothesis by Bakun (1990), later taken up by McGregor et al. (2007) for NW Africa, which proposes a general increase in coastal upwelling in the later part of the 20th century due to global warming. On the other hand, trends obtained from the NCEP/NCAR and ERA-40 wind stress for the areas off NW Africa as well as the study by Lemos and Pires (2004), which argues that the upwelling intensity has decreased over the last century at the coast of Portugal, suggest that coastal upwelling intensity is increasing in some upwelling regions and decreasing in others.

At first sight the lack of significant trends in the Lüderitz (ERA-40 dataset) and California (NCEP/NCAR dataset) and 

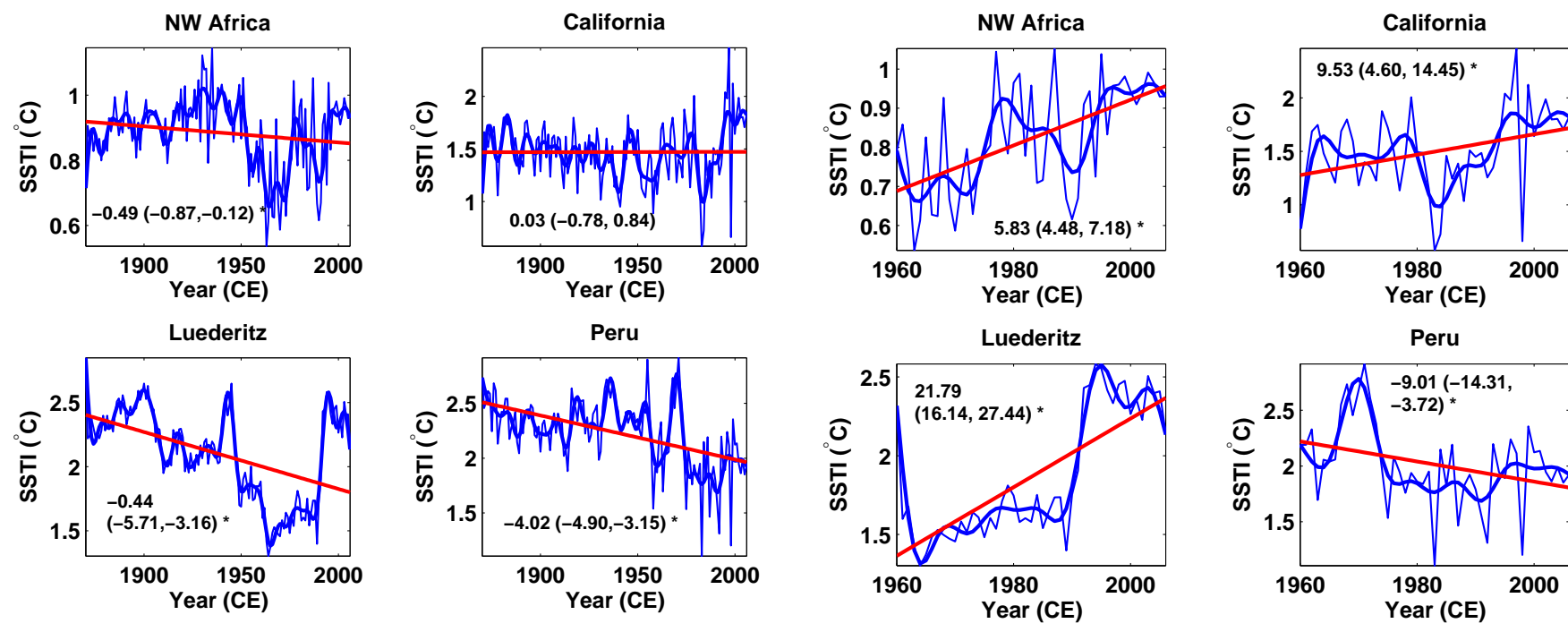

Fig. 6. Trends of coastal upwelling derived from the HadISST dataset (Rayner et al., 2003), for the period 1870-2006. Significant decreasing trends are observed at NW Africa, Lüderitz and Peru. The value of the slope and its $95 \%$ confidence interval are given in each panel (in units of $10^{-3}{ }^{\circ} \mathrm{C} \mathrm{yr}^{-1}$ ). A * indicates that the slope is statistically significant at the 0.05 level. Also shown are the unsmoothed time series (thin lines).

the existence of significant decreasing trends revealed by the NCEP/NCAR dataset for the NW African and Peruvian upwelling regions indeed seem to contradict the global nature of increasing coastal upwelling intensity as proposed by Bakun (1990). However, Smith et al. (2001) argue that the NCEP/NCAR reanalysis dataset underestimates the strength of wind globally. They also suggest that the surface pressure is significantly weaker in the tropics, which leads to an underestimation of the strength of subtropical highs and the wind strength, specifically in the subtropics. Moreover, the comparison of NCEP/NCAR winds with COADS winds by $\mathrm{Wu}$ and Xie (2003) revealed that the COADS inter-decadal wind changes are more consistent with independent observations. Based on these findings we assume that the trends observed in the COADS dataset are likely to be more reliable.

Ramage (1987) and Cardone (1990) give many reasons for the likelihood of an artificial long-term trend contaminating the wind stress time series (especially the COADS dataset), for example, the one related to the monotonically increasing proportion of anemometer measurements to Beaufort estimates in the available distribution of maritime wind reports. Bakun (1992) analysed the wind stress trends obtained off the Iberian peninsula and detected that there exist two overlapping trends, one related to the artifact and one thought to be associated with the gradual strengthening of continental thermal low pressure cells. Since separating the effect of their respective roles was difficult, Bakun (1992) analyzed the spatial patterns of the wind stress trend in the periphery of the North Atlantic gyre and determined that the long-term trends adjacent to the seasonally heated land masses showed

Fig. 7. Trends of coastal upwelling derived from the HadISST dataset (Rayner et al., 2003) for the period 1960-2006. The upwelling shows an increase after 1960 in all regions except Peru. The value of the slope and its $95 \%$ confidence interval are given in each panel (in units of $10^{-3}{ }^{\circ} \mathrm{C} \mathrm{yr}^{-1}$ ). A $*$ indicates that the slope is statistically significant at the 0.05 level. Also shown are the unsmoothed time series (thin lines).

increasing trends, whereas the locations away from these regions showed decreasing trends. Additionally, Mendelssohn and Schwing (2002) show that the increasing wind stress is confined to the main upwelling zone as well as the seasonal period in which the thermal low pressure zone develops. Fortunately, the problem arising from the increasing proportion of anemometer measurements to Beaufort estimates is more prevalent in the time period 1900-1950 (Cardone, 1990). Since our analysis is mainly based on the data after the 1960s the effect of the artificially generated trend will be minimal. The high degree of scatter in the time series which is independent of the increasing trends, could be from the above mentioned reasons.

SST has been used as an indicator of coastal upwelling in previous studies (Nykjaer and Van Camp (1994) McGregor et al., 2007). But the SST along the upwelling-affected nearcoastal segment is a mixed signal, which could be altered by various factors. For example, decrease of surface mixing in the ocean could affect the offshore SST gradient. Similarly, intense storm activity in the offshore regions could deepen the mixed layer offshore while entraining cooler waters into the surface affecting the SST. Long-term changes, such as climate change related relaxation of the equatorial Walker circulation (Vechi et al., 2006) could also change the SST gradient. Therefore an increase/decrease of SST along the coastal upwelling zone cannot be used as a primary indicator of coastal upwelling intensity, but it can be used as a secondary indicator of coastal upwelling intensity when there is an associated increase in the upwelling favorable wind. 

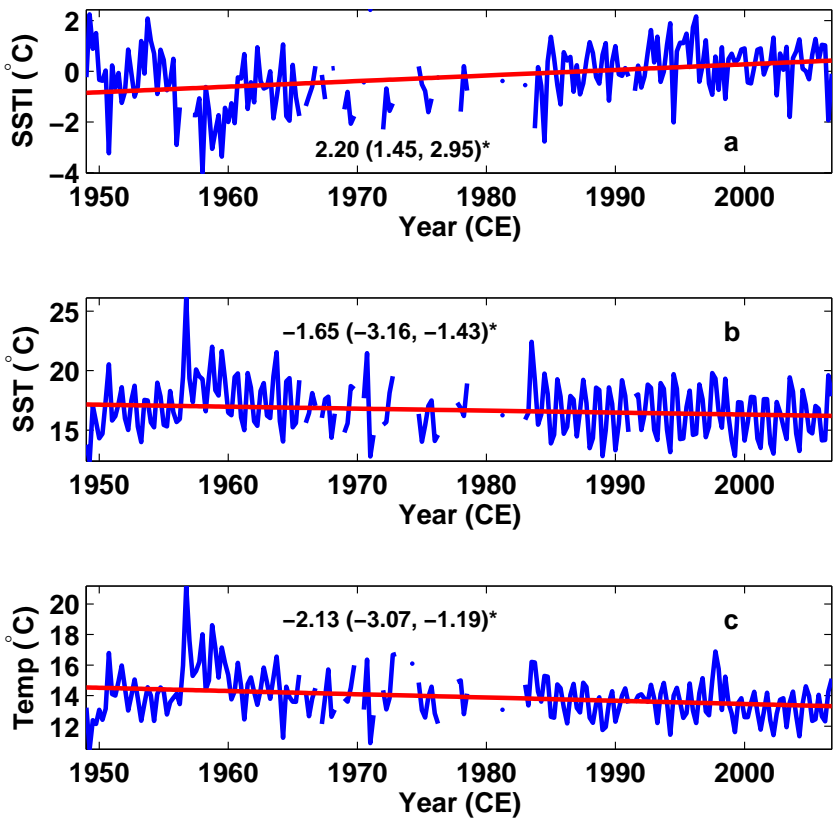

Fig. 8. (a) Linear trend of the upwelling index derived from the CALCOFI (Bograd et al., 2003) SST dataset estimated using the method of least squares and using the datapoints shown in Fig. 2. (b) Linear trend of SST in coastal California estimated from the CALCOFI dataset. The trend indicates a significant cooling over the last 45 years. (c) Linear trend of the coastal temperature averaged over top $100 \mathrm{~m}$ of the water column off California estimated from the CALCOFI dataset. The value of the slope and its $95 \%$ confidence interval are given in each panel (in units of $10^{-2}{ }^{\circ} \mathrm{C} \mathrm{yr}^{-1}$ ). $\mathrm{A} *$ indicates that the slope is statistically significant at the 0.05 level.

The trend observed in the SST index derived from the HadISST in the later part of the 20th century (1960-2006) also showed a significant increase of upwelling in all regions except Peru and is thus consistent with the wind stress derived from the COADS data. It should be noted that the trend obtained from the HadISST data after 1960 off Peru demonstrates a significant decrease of upwelling even when upwelling favourable winds derived from the COADS dataset and the ERA 40 dataset show a significant increase. A comparison of the filtered and unfiltered SST index for the Peruvian upwelling region with the MEI (Fig. 9) reveals that the time interval 1962-1975 was predominantly in the cooler than normal (La Niña) phase, whereas the MEI indicates predominantly warmer than normal conditions after 1975. The presence of a relatively cool phase in the earlier part of the time series and a relatively warm phase in the later part effectively led to an apparent decrease of coastal upwelling. This is reflected even in the filtered time series where the peaks associated with the El Niño/La Niña are removed.

The trends obtained from the CALCOFI SST index and coastal temperatures indicate a significant cooling trend. This further substantiates the result obtained from COADS

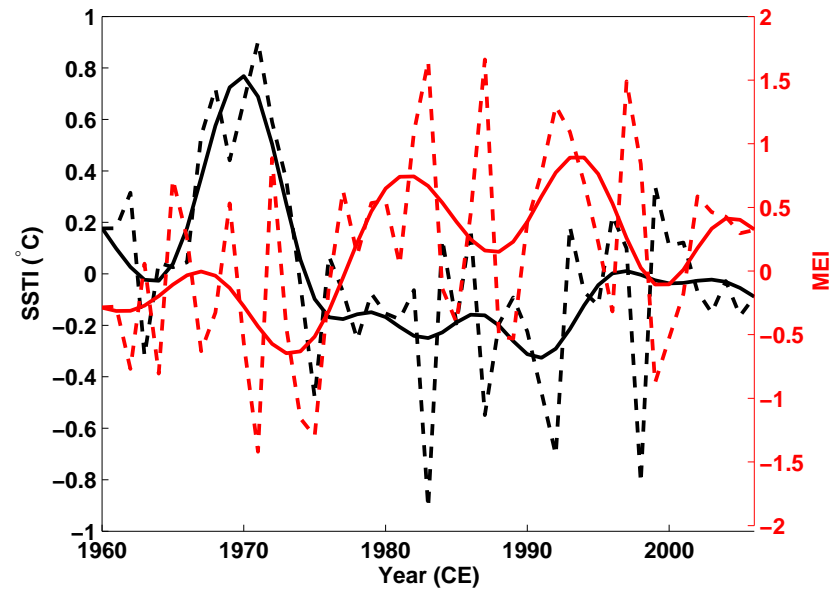

Fig. 9. Comparison of filtered (black) and unfiltered (black dash) SST index (mean removed) off Peru upwelling region with filtered (red) and unfiltered (red dash) Multivariate ENSO Index (MEI; Wolter and Timlin, 1993).

wind stress and the HadISST index. It is also consistent with the increase in net primary production inferred from satellite observations from 1997 to 2007 (Kahru et al., 2009).

The coastal upwelling areas especially off NW Africa and California are subject to basin-scale climate oscillations like the Atlantic Multidecadal Oscillation (AMO), the North Atlantic Oscillation (NAO) and the Pacific Decadal Oscillation (PDO). So the trends observed in the upwelling intensity could be affected by these basin-scale oscillations. In the following we want to exclude the possibility that these oscillations exert a primary control over the intensity of coastal upwelling.

With regard to the possible control of the upwelling intensity by basin-scale climate oscillation, Pearson's correlation coefficient (see Table 2) showed that the correlation between the upwelling indices off NW Africa and the AMOI is insignificant. Furthermore, the NAOI shows a significant negative correlation with the meridional wind stress off NW Africa, but the correlation with the SST index is insignificant. Finally, the correlation coefficient between the PDOI and the SST index of coastal upwelling indices off California showed a weak but significant correlation, but the correlation with alongshore wind stress was found to be insignificant.

Cross-correlation analyses (not shown) between the upwelling indices off NW Africa and the AMOI revealed the lack of correlation at all lags. The cross-correlation between NAOI and upwelling indices off NW Africa also showed no significant correlation at any lag. In the North Pacific, the PDOI and upwelling indices off California also failed to show any substantial cross-correlation at any lag. Francis et al. (1998) observed that during the positive phase of the PDO, salmon fish catches have been significantly reduced in the California Current System and the associated upwelling region. Since the PDO reversed its direction in 1977 to its 
Table 2. Pearson's correlation coefficients for the basin-scale oscillations AMO, NAO with the upwelling indices off NW Africa and PDO with upwelling index off California. Values in parentheses denote the $95 \%$-bootstrap confidence intervals for the correlation coefficient. A * indicates that the correlation is statistically significant at the 0.05 level.

\begin{tabular}{llrr}
\hline Climate Index & Region & Wind stress from COADS & SST index from HadISST \\
\hline AMOI & NW Africa & $-0.012(-0.149,0.196)$ & $0.040(-0.045,0.129)$ \\
NAOI & NW Africa & $-0.163(-0.250,-0.066)^{*}$ & $0.069(-0.126,0.257)$ \\
PDOI & California & $0.031(-0.067,0.118)$ & $-0.304(-0.383,-0.221)^{*}$ \\
\hline
\end{tabular}

positive phase and remained in it until late 1990s, the majority of the data used in our study originate from a positive phase of the PDO. Correlation and cross-correlation analyses were done to check the influence of the PDO on the coastal upwelling off California. A weak but significant negative correlation $-0.304(-0.383,-0.221)$ was observed with the SST index, that is, weaker upwelling during a positive phase of the PDO. However, the correlation between the PDO and wind stress was insignificant. According to Roemmich and McGowan (1995), the warming associated with the shift towards the positive phase of the PDO increases the stratification, which in turn would result in the reduced displacement of the thermocline and increase the temperature of the upwelled water. Therefore the PDO may exert a certain amount of control on SST in the California region, but not neccessarily on the wind stress. In line with the Bakun hypothesis, the increasing trend in wind stress could be due to global warming and, hence, exert an independent control on SST.

The North Atlantic Oscillation could influence the coastal upwelling intensity off the NW-African region because of its influence on the Azores high (Knippertz et al., 2003). The NAO also has a very important role in the long-term variability of the wind in the North Atlantic (Santos et al., 2005). The NAO was in the negative phase at the start of the data used in our analysis, changing to its positive phase during the early 1980s. Since two different phases of the NAO were present in the period of our study, we may expect an influence of the NAO on the trend of coastal upwelling. Hence a correlation analysis was conducted between the NAO index and the upwelling indices off NW Africa to disentangle any plausible relation between the two (Table 2). The correlation analysis revealed a significant negative correlation with the alongshore wind stress but an insignificant correlation with the SST index. The cross-correlation analysis also did not reveal any relation between the upwelling index and the NAO. The lack of correlation between the SST index and the NAO is quite ambiguous considering a significant negative correlation with the alongshore wind stress. Hence the influence of the NAO on the increasing trend of coastal upwelling could not be substantiated.

Similarly, the AMO is also a main factor in the long term evolution of wind and SST in the North Atlantic. Knight et al. (2006) argue that during the warm phase of the AMO there are consistent changes of the trade winds over the Sahel region and also a northward displacement of the mean Inter Tropical Convergence Zone. The North Atlantic experienced a change from a warm phase to a cold phase in the mid1960s, and the AMO again shifted to a warm phase during the mid 1990s. Accordingly, change in the trade-wind patterns associated with the changing phase of the AMO could be a considerable factor in determining the long-term trend of coastal upwelling intensity. However, the correlation between the AMO index and coastal upwelling indices were statistically insignificant, which allows us to disregard any primary control of the AMO over the intensity of coastal upwelling off NW Africa.

The major physical factor that controls coastal upwelling intensity along the eastern boundaries of the oceans is the equator-ward alongshore wind stress component. The hypothesis proposed by Bakun (1990) puts forth a mechanism by which the wind stress that favours the upwelling increases due to the greenhouse gas-induced warming and subsequent changes in the land-sea pressure gradient. This mechanism may also serve as an explanation for the trends in the COADS wind stress data and the SST indices derived from the HadISST and the CALCOFI SST datasets.

The effect of atmospheric aerosols on the strength of upwelling favorable winds is not very well understood. However, atmospheric aerosols that absorb and scatter solar radiation tend to decrease near surface wind speeds by up to $8 \%$ locally (Jacobson and Kaufman , 2006). Therefore, the presence of aerosols, soot and dust from both anthropogenic and natural (e.g. volcanism) sources might be an important factor, which could influence the intensity of coastal upwelling locally. Similarly, solar insolation variability could also affect upwelling favorable winds, thereby altering the intensity of coastal upwelling. Stratification is another important factor in determining the depth from which the water upwells, which in turn affects the coastal SST and nutrient concentration. Upwelling due to divergence in the alongshore current and topographic steering is another possible process by which the rate of upwelling can be altered over time. But the effect of these processes on long-term variability in a coastal upwelling system is not well documented. 


\section{Conclusions}

From the analysis of trends in wind stress obtained from the COADS, NCEP/NCAR and ERA 40 datasets, we found that there were large discrepancies between the datasets. Based on the comparisons done in previous studies, we consider the trends obtained from the COADS dataset to be most reliable. These trends indicate an increase of coastal upwelling in all major upwelling regions.

The SST index obtained from the HadISST data suggests a decrease of coastal upwelling after 1870. However, after 1960 the same SST index also shows a significant increase of coastal upwelling in all regions except for Peru. Additionally, the CALCOFI dataset presents strong evidence for the intensification of upwelling in the California upwelling region.

Our study revealed that the AMO does not directly interact with upwelling off NW Africa. The influence of the NAO with upwelling off NW Africa seems to be quite ambiguous, as a negative correlation between the NAOI and meridional wind stress is observed, but a complete lack of correlation with the SST index was found. In the Pacific the PDOI also shows a weak correlation with upwelling off California, indicating a lack of any direct interaction.

In summary, the hypothesis proposed by Bakun (1990) and later taken up by McGregor et al. (2007), which states there is an intensification of coastal upwelling in relation to global climate change, gains some additional support by our analysis of the COADS wind stress data, the SST index derived from the HadISST data (after 1960) and the SST index derived from the CALCOFI data set. The lack of correlation between the basin-scale oscillations like the AMO, the NAO and the PDO also rules out an alteration of upwelling intensity other than due to enhanced upwelling-favourable winds by the mechanism proposed by Bakun (1990), although other physical factors like changes in stratification, atmospheric aerosols and solar variability could not be excluded.

Acknowledgements. The study is funded through DFG-Research Center/Excellence Cluster "The Ocean in the Earth System" and the "Bremen International Graduate School for Marine Sciences (GLOMAR)". We would also like to thank Andrew Bakun and an anonymous reviewer for their useful comments on the manuscript.

Edited by: M. Meier

\section{References}

Bakun, A.: Global climate change and intensification of coastal ocean upwelling, Science, 247, 198-201, 1990.

Bakun, A., Global greenhouse effects, multi-decadal wind trends and potential impacts on coastal pelagic fish populations, ICES Mar. Sc., 195, 316-325, 1992.
Barnston, A. G. and Livezey, R. E.: Classification, seasonality and persistence of low-frequency atmospheric circulation patterns, Mon. Weather Rev., 115, 1083-1126, available at: http://www.cpc.noaa.gov/products/precip/CWlink/pna/norm. nao.monthly.b5001.current.ascii, 1987.

Bograd, S. J., Checkley Jr., D. A, and Wooster, W. S.: CalCOFI: a half century of physical, chemical, and biological research in the California Current System, Deep Sea Res. Pt. II, 50, 14-16, 2003.

Borges, M. F., Santos, A. M. P., Crato, N., Mendes, H., and Mota, B.: Sardine regime shifts off Portugal: a time series analysis of catches and wind conditions, Sci. Mar., 67, 235-244, 2003.

Cardone, V. J., Greenwood, J. G., and Cane, M, A.: On trends in historical wind data, J. Climate, 3, 113-127, 1990.

Dawdy, D. R. and Matalas, N. C.: Statistical and probability analysis of hydrologic data, Part 3, analysis of variance, covariance, and time series, Handbook of Applied Hydrology Ed. Ven Te Chow, McGraw-Hill, New York, 1964.

Dunbar, R. B.: Stable isotope record of upwelling and climate from Santa Barbara Basin, California Coastal Upwelling, Its Sediment Rec., edited by: Thiedel, J. and Suess, E., Plenum, New York, 217-246, 1983.

Ekman, W. K.: On the influence of earth's rotation on ocean currents, Arkiv för Matematik, Astronomi och Fysik, 2, 1-53, 1905.

Enfield, D. B., Mestas-Nunez, A. M., and Trimble, P. J.: The Atlantic Multidecadal Oscillation and its relationship to rainfall and river flows in the continental US, Geophys. Res. Lett., 28, $2077-$ 2080, available at: http://www.cdc.noaa.gov/data/correlation/ amon.sm.data, 2001.

Francis, C. R., Hare, S. R., Hollowed, A. B., and Wooster, W. S.: Effects of interdecadal climate variability on the oceanic ecosystem of the NE Pacific, Fish. Oceanogr., 7, 1-21, 1998.

Hagen, E.: Mesoscale upwelling variations off the West African coast, Coastal Upwelling, edited by: Richards, F. A., American Geophysical Union, 72-78, 1981.

Jacobson, M. Z. and Kaufman, Y. J.: Wind reduction by aerosol particles, Geophys. Res. Lett., 33, L24814, doi:10.1029/2006GL027838, 2006.

Jin, F. F.: An equatorial ocean recharge paradigm for ENSO. Part I: conceptual model, J. Atmos. Sci., 54, 811-829, 1997.

Juillet-Leclerc A. and Schrader H.: Variations in upwelling intensity recorded in varved sediment from the Gulf of California during the past 3000 years, Nature, 329, 146-149, 1987.

Kahru, M., Kudela, R., Manzano-Sarabia, M., and Mitchell, B. G.: Trends in primary production in the California Current detected with satellite data, J. Geophys. Res., 114, C02004, doi:10.1029/2008JC004979, 2009.

Kalnay, E., Kanamitsu, M., Kistler, R., Collins, W., Deaven, D., Gandin, L., Iredell, M., Saha, S., White, G., Woollen, J., Zhu, Y., Chelliah, M., Ebisuzaki, W., Higgins, W., Janowiak, J., Mo, K. C., Ropelewski, C., Wang, J., Leetmaa, A., Reynolds, R., Jenne, R., and Joseph, D.: The NCEP/NCAR 40-Year Reanalysis Project, B. Am. Meteorol. Soc., 77(3), 437-471, 1996.

Kaplan, A., Cane, M., Kushnir, Y., Clement, A., Blumenthal, M., and Rajagopalan, B.: Analyses of global sea surface temperature 1856-1991, J. Geophys. Res., 103, 18567-18589, 1998.

Knight, J. R., Folland, C. K., and Scaife, A. A.: Climate impacts of the Atlantic Multidecadal Oscillation, Geophys. Res. Lett., 33, L17706, doi:10.1029/2006GL026242, 2006. 
Knippertz, P., Christoph, M., and Speth, P.: Long-term precipitation variability in Morocco and the link to large-scale circulation in recent and future climates, Meteorol. Atmos. Phys., 83, 67-88, 2003.

Lemos, R. T. and Pires, H. O.: The upwelling regime off the West Portuguese Coast, 1941-2000, Int. J. Climatol., 24, 511-524, 2004.

Mantua, N. J., Hare, S. R., Zhang, Y., Wallace, J. M., and Francis, R. C.: A Pacific interdecadal climate oscillation with impacts on salmon production, B. Am. Meteorol. Soc., 78, 1069-1079, available at: http://jisao.washington.edu/pdo/PDO.latest, 1997.

McGregor, H. V., Dima, M., Fischer, H. W., and Mulitza, S.: Rapid 20th-century increase in coastal upwelling off Northwest Africa, Science, 315, 637-639, doi:10.1126/science.1134839, 2007.

Mendelssohn, R. and Schwing, F. B., Common and uncommon trends in SST and wind stress in the California and Peru-Chile current systems, Prog. Oceanogr, 53, 141-162, 2002.

Mudelsee, M.: Estimating Pearson's correlation coefficient with bootstrap confidence interval from serially dependent time series, Math. Geol., 35, 651-665, 2003.

Nykjaer, L. and Van Camp, L.: Seasonal and interannual variability of coastal upwelling along northwest Africa and Portugal from 1981 to 1991, J. Geophys. Res., 99, 14197-14207, 1994.

Orfanidis, S. J.: Optimum Signal Processing. An introduction, 2nd Edition, Prentice-Hall, Englewood Cliffs, NJ, 1996.

Pauly, V. and Christensen, V.: Primary production required to sustain global fisheries, Nature, 374, 255-257, 1994.

Pedlosky, J.: A nonlinear model of onset of coastal upwelling, J. Phys. Oceanogr., 8, 178-187, 1978.

Ramage, C. S.: Secular change in reported wind speeds over the ocean, J. Clim. Appl. Meteorol., 26, 525-528, 1987.

Rayner, N. A., Parker, D. E., Horton, E. B., Folland, C. K., Alexander, L. V., Rowell, D. P., Kent, E. C., and Kaplan, A.: Global analyses of SST, sea ice and night marine air temperature since the late nineteenth century, J. Geophys. Res., 108(D14), 4407 doi:10.1029/2002JD002670, 2003.

Roemmich, D.: Ocean warming and sea level rise along the South West US coast, Science, 257, 373-375, 1992.

Roemmich, D. and McGowan, J.: Climatic warming and the decline of zooplankton in the California current, Science, 267, 324-326, 1995.
Santos, A., Miguel P., Kazmin, A. S., and Álvaro, P.: Decadal changes in the Canary upwelling system as revealed by satellite observations: Their impact on productivity, J. Mar. Res., 63, 359-379, 2005.

Slutz, R. J., Lubker, S. J., Hiscox, J. D., Woodruff, S. D., Jenne, R. L., Joseph, D. H., Steurer, P. M., and Elms, J. D.: Comprehensive Ocean-Atmosphere Data Set; Release 1. NOAA Environmental Research Laboratories, Climate Research Program, Boulder, CO, 268 pp. (NTIS PB86-105723), 1985.

Smith, R. L.: A comparison of the structure and variability of the flow filed in three coastal upwelling regions, Oregon North West Africa and Peru, Coastal Upwelling, edited by: Richards, F. A., American Geophysical Union, 107-118, 1981.

Smith, S. R., Legler, D. M., and Verzone, V. M.: Quantifying Uncertainties in NCEP Reanalyses Using High-Quality Research Vessel Observations, J. Climate, 14, 4062-4072, 2001.

Uppala, S. M., Kållberg, P. W., Simmons, A. J., Andrae, U., da Costa Bechtold, V., Fiorino, M., Gibson, J. K., Haseler, J., Hernandez, A., Kelly, G. A., Li, X., Onogi, K., Saarinen, S., Sokka, N., Allan, R. P., Andersson, E., Arpe, K., Balmaseda, M. A., Beljaars, A. C. M., van de Berg, L., Bidlot, J., Bormann, N., Caires, S., Chevallier, F., Dethof, A., Dragosavac, M., Fisher, M., Fuentes, M., Hagemann, S., Hólm, E., Hoskins, B. J., Isaksen, L., Janssen, P. A. E. M., Jenne, R., McNally, A. P., Mahfouf, J.-F., Morcrette, J.-J., Rayner, N. A., Saunders, R. W., Simon, P., Sterl, A., Trenberth, K. E., Untch, A., Vasiljevic, D., Viterbo, P., and Woollen, J.: The ERA-40 re-analysis, Q. J. Roy. Meteorol. Soc., 131, 2961-3012, 2005.

Vecchi, G. A., Soden, B. J., Wittenberg, A., Held, I. M., Leetma, A., and Harrison, M. J.: Weakening of tropical Pacific atmospheric circulation due to anthropogenic forcing, Nature, 425, 73-76, 2006.

Wolter, K. and Timlin, M. S.: Monitoring ENSO in COADS with a seasonally adjusted principal component index. Proc. of the 17th Climate Diagnostics Workshop, Norman, OK, NOAA/NMC/CAC, NSSL, Oklahoma Clim. Survey, CIMMS and the School of Meteor., Univ. of Oklahoma, 52-57, available at: http://www.esrl.noaa.gov/psd/people/klaus.wolter/MEI/table. html, 1997.

Wu, R. and Xie, S. P.: On Equatorial Pacific Surface Wind Changes around 1977: NCEP-NCAR Reanalysis versus COADS Observations, J. Climate, 16, 167-173, 2003. 